\title{
Investigation of the correlation between science teachers' level of use of the education information network and their level of use of technology
}

\author{
Figen DURKAYA * \\ Department of Mathematics and Science Education, Faculty of Education, Kirlkkale \\ University, Kirikkale, Turkey, ORCID: 0000-0002-5639-717X
}

Gizem LOKUMCU BAŞYIĞIT

Institute of Education Sciences, Kırlkkale University, Kirikkale, Turkey, ORCID: 0000-0002-6564-3440

Article history

Received:

04.05.2021

Received in revised form: 01.11.2021

Accepted:

18.11.2021

Key words:

Education information network, correlation research model, science teachers
The Education Information Network (EBA), which is offered as a social education platform in Turkish education system, is a system that allows teachers and students to benefit from educational technologies free of charge. This research was carried out to determine the correlation between the level of use of the EBA and the level of use of educational technologies of science teachers working in secondary education. In the study, the correlation research model, which is a quantitative research method, was used. The study group of the research consist of 80 Science Teachers working in all public secondary schools in the district of Corlu in the province of Tekirdağ in the spring term of the 2018-2019 Academic year. As the data collection tool, Alabay's "Opinions on EBA Usage Level" and Bayraktar's "Educational Technologies Usage Level Determination Questionnaire" were used to determine the demographic characteristics of the participants. The data was analyzed by using SPSS 23 statistical analysis software package. The results of the study were obtained by applying the normality test, nonparametric analyses (Mann Whitney U test and Kruskal Wallis $\mathrm{H}$ test) and the Correlation analysis on the obtained data. When the correlation between the opinions of teachers concerning the level of use of the EBA and the level of use of the educational technologies were examined, a positive and significant correlation was found between them.

\section{Introduction}

Today, technology takes place in every aspect of our life and makes our lives easier. The continual increase in the use of technology allows the change and equality of opportunity in education as in all other aspects of life. Turkey has kept up with responded to this change created by the technology in the educational systems around the world by developing the projects of "Support to Computerized Education", "A Computer to Each Classroom", "100\% Support to Education", and, most recently, the FATİH Project (Demir, Özdinç and Ünal, 2018).

The Ministry of National Education has developed the FATİH (Increasing Opportunities and

\footnotetext{
* Correspondency: figendurkaya@kku.edu.tr
} 
Improving Technology Movement) Project involving the use of Computer Technology (CT) that aims to increase the use of technology at schools (Kuyubaşığlu and Kılıç, 2019). The FATİH Project has made it possible to use the technologies provided by internet access along with traditional learning methods. Within the context of providing and managing the educational e-content for the use of technology in classrooms in the educational system of Turkey, the EBA, an online social education platform offered free of charge to teachers and students, has been developed and presented by the General Directorate of Innovation and Educational Technologies. The primary purpose of the EBA is, as is the case for the FATİH Project, to continue to fulfill the principle of "Equality of Opportunity in Education" (Aktay and Keskin, 2016; Arkan and Kaya, 2018).

In this process, schools around Turkey became acquainted with the educational platform EBA and started to use technology in education. The use of technology in education has gained importance since it includes activities that are compatible with the theory of multiple intelligences, which is one of the learning approaches. It includes various senses into the learning-teaching activities. In addition, activities or experiments that cannot be done in learning environments due to various reasons have become easily accessible through technology (Saklan \& Ünal, 2018). EBA includes contents such as news, videos, various images, audio videos, e-books, e-magazines, e-documents; contests, e-courses, distant learning and lifelong learning shares, and various courses compatible with the levels of primary and secondary education.

Introduction of the EBA, one of the educational technologies projects, has created a process of change both in the educational system of Turkey and in the teachers of the country. In this context, the success of educational technologies projects depends on the requirement for developing teachers' cognitive and affective features concerning the developing technology beyond the process of providing the technological devices and equipment (Demirarslan and Usluel, 2005). Thus, teachers need to improve the level of their use of technology to a reasonable level.

The EBA, which was put into practice by the Ministry of National Education through the FATIH Project in 2010, has been the subject of various studies since then. It has been determined that the studies in the literature have addressed the subject in terms of three distinct aspects. It has been found out that the studies on these subjects are about the role and functionality of the EBA in education, the opinions of teachers on the levels of use of the EBA platform, and the opinions of students on the EBA platform.

It has been suggested in the studies in the literature that have been conducted to investigate the role and functionality of the EBA in education, that the EBA is a source containing materials that are cheap, useful, and easily accessible by teachers and students in educational terms. In addition, when the content of the EBA has been examined, it has been found to have two ways of use in terms of functionality. The first of these two ways is that the teachers can teach the lesson by sharing the materials they have prepared in the classes opened based on their own initiative. As for the second way of use of the EBA, it has been stated that they can share the activities that are included in the content category of the EBA and are commonly accessible for teachers and students (Aktay and Keskin, 2016; Arkan and Kaya, 2018).

It has been determined that there is a great number of studies in the literature in which the opinions of teachers concerning the levels of the use of the EBA. The studies conducted concerning the EBA include the statements of teachers' expressing their opinions concerning 
the levels of the use of the EBA (Çakmak and Taşkıran, 2017; Fidan, Erbasan and Kolsuz, 2016; Güvendi, 2014; Kuyubaşığlu and Kılıç, 2019; Saklan and Ünal, 2018; Ünal and Hastürk, 2018; Tutar, 2015; Türker and Güven, 2016; Varışoğlu, 2019). However, few studies are observed in which only students' views on EBA are examined. In the studies conducted concerning that subject, the students' levels of use of the EBA portal and their opinions about the system were evaluated (Bertiz, 2017; Timur, Yılmaz and İşseven, 2017; Tüysüz and Çümen, 2016). Likewise, it has also been found out that some studies have been conducted to determine the students' purpose of using the EBA, their frequency of logging in the system, their opinions on the aspects of the system in need of being improved, and the benefits of the system in their eyes. In a study conducted by Durmuşçelebi and Temircan (2017) with a different approach, the objective was to determine the students' opinions concerning the educational materials and course contents in the EBA.

Studies addressing and investigating the opinions of both the teachers and the students in secondary education concerning the EBA have also been found in the literature. Demir, Özdinç and Ünal (2018) analyzed the statistics concerning the participation in schools based on the EBA in their study. By analyzing the statistics concerning the participation in the EBA portal, they evaluated the opinions about the EBA of the teachers and students using the portal the most. Kalemkuş (2016) conducted a study aimed at determining the opinions of teachers and students concerning the EBA and their purposes of use of the portal. Alabay and Taşdelen (2017) investigated the levels of use of the EBA and the opinions about the EBA in terms of the variables. Kapıdere and Çetinkaya (2017) investigated in their study the use of the mobile application of the EBA among teachers and students. Yirci and Bulduk (2018) conducted a study to determine teachers and students' opinions about the weaknesses and strengths of the EBA and its improvability.

In the literature, studies are found on the level of use of educational technologies by science teachers in lessons. In the study conducted by Akpınar, Aktamış and Ergin (2005), the opinions of students concerning the use of technology in Science lessons were taken, and the frequency by which the Science teachers use the devices and equipment of educational technology in their lessons was investigated. Demirhan (2012) investigated the self-efficacy perceptions of Science teachers concerning the information and communication techniques and their status in terms of using the technology in their lessons. In a number of studies conducted previously, the opinions of subject matter teachers concerning using teaching technologies in their classes (Türk, 2012) and the problems encountered by the subject matter teachers at primary education in their use of the information technologies have been evaluated (Gülcü et al., 2013).

It is seen that education in the world has been managed with e-learning platforms using information technologies in recent years. Following the trends and educational vision in the world, Turkey also aimed to improve its educational system by putting the EBA into practice and made a considerable amount of investment in its system. EBA, which can create a difference in education when used effectively and ensure social transformation with the results achieved, is an effective source for the Ministry of National Education (Arkan and Kaya, 2018). In this context, teachers in our education system need to be supported in order to improve their level of using technology. It was found out in the literature that there are significant number of studies investigating teachers' opinions concerning the level of use of the EBA. Likewise, it has also been determined that there are studies that have independently investigated the views on the status of teachers' use of technology in their lessons. However, there is no previous study analyzing the correlation between the level of use of the EBA and 
the use of technology. In line with this information, the rationale of the research is to research the correlation between the level of Science Teachers' use of EBA and the level of technology use. To ensure the solution of the defined problem, the sub-problems listed below have been analyzed within the scope of the study. Within this scope, answers were sought for the following questions:

- Do the opinions of science teachers concerning the use of the EBA differ depending on their gender and duration of professional service?

- Do the science teachers' level of use of the educational technology differ depending on their gender and duration of professional service?

- Is there a correlation between the science teachers' level of use of the EBA and their level of use of the educational technologies?

\section{Methodology}

\section{Model of the Study}

In the present study, which was conducted in order to determine the correlation between the level of use of the EBA by Science teachers and their level of use of the technology, the correlational research model was used. Definition and investigation of human behaviors is a rather complex process. The way of making this process a little bit more understandable can be possible by determining the correlations at a simpler level. In other words, the correlational research method is used to see the relationship between two or more variables, whether the variables affect each other. (Büyüköztürk, 2012).

\section{Target Population and Sample}

The study was conducted with 80 Science Teachers serving at the public middle schools affiliated with the Ministry of National Education and located in the district of Çorlu in the province of Tekirdağ in the Spring Term of the 2018-2019 academic year. The study used the random sampling method which is under the probability-based sampling methods, was used in the research. The random sampling method suggests that it is possible to select a sampling with a size that can represent the target group on a completely random basis (Yildirım and Şimşek, 2016). Necessary permissions were obtained from the relevant institutions and persons due to ethical rules. The participants were given the guarantee that their names would not be revealed in the findings to be obtained from them and in the study itself, and that this information would be kept confidential. Concerning the quantitative data, the demographical characteristics of the teachers are given in Table 1.

Table 1. Demographical characteristics of teachers

\begin{tabular}{llrr}
\hline & & $\mathrm{f}$ & $\%$ \\
\hline Gender & Female & 56 & 70 \\
Educational Status & Male & 24 & 30 \\
& Bachelor's Degree & 78 & 97.5 \\
Duration of Professional Service & Postgraduate Degree & 2 & 2.5 \\
& $1-5$ Years & 15 & 18.8 \\
& 6-10 Years & 41 & 51.2 \\
& $11-15$ Years & 11 & 13.8 \\
\hline
\end{tabular}


It can be seen in Table 1 that $70 \%$ of the Science Teacher constituting the sample were female and $30 \%$ were male, $97.5 \%$ had a bachelors' degree and the duration of service in the profession was between 6 and 10 years for $51.2 \%$.

\section{Data Collection Tools}

The data was obtained by using two scales in this study. The "Questionnaire for the Opinions concerning the Level of Use of the EBA" developed by Alabay (2017), and the "Questionnaire for Determining the Level of Use of the Educational Technologies" developed by Bayraktar (2015) were used in order to determine the Science Teachers' level of use of the EBA and the educational technologies.

The questionnaire used to determine the opinions of the Science Teachers concerning the level of use of the EBA comprised three dimensions, namely "the opinions concerning the EBA" (Item 11), "the level of use of the EBA" (Item 16), and "the Solution Offers concerning the Improvement of Education and Training by means of the EBA" (Item 11). In addition, the Questionnaire for the Opinions concerning the Level of Use of the EBA was composed of 38 items using a three-point Likert-type scale. The internal consistency coefficient for the reliability of the questionnaire applied to determine the opinions of Science Teachers concerning the use of the EBA (Cronbach Alpha) was found to be 0.955.

The questionnaire applied to determine the opinions of Science Teachers concerning the level of use of the Educational Technologies was composed of four dimensions, namely "the Technological Literacy" (19 items), "Integration of Technology into the Lessons" (9 items), "Social Ethics and Legal Provisions" (6 items) and "Communication" (4 items). The Questionnaire for the Opinions concerning the Level of Use of the Educational Technologies was composed of 38 items using a five-point Likert-type scale. Considering the reliability of the questionnaire used to determine their opinions on the level of educational technology use, the Cronbach Alpha internal consistency coefficient was found to be 0.909 .

\section{Data Analysis}

The data was analyzed by using SPSS 23 statistical analysis software package. Frequency (f), percentage (\%), arithmetic mean (X) and standard deviation (SD) expressions were used in descriptive statistics. The results of the study were obtained by applying the normality test, nonparametric analyses (Mann Whitney U test and Kruskal Wallis H test) and the Correlation analysis on the obtained data. The level of significance was taken to be 0.05 at the present study.

In order to use parametric tests in the analysis of data in the research, the data should be normally distributed and homogeneous. The cases when the data is not normally distributed, non-parametric tests should be used. Büyüköztürk (2012) suggests the use of KolmogorovSmirnov test when the number of subjects is over 50 in the normality tests. Thus, the compliance of the data to the normal distribution was determined by means of the Kolmogorov-Smirnov test in this study. According to Kolmogorov-Smirnov test results, the $p$ (Sig) value was $\mathrm{p}=.000$. Thus, it can be said that the data did not have a normal distribution. Since the items of the scale did not have a normal distribution $(\mathrm{p}<0.05)$, nonparametric tests were applied. 


\section{Findings}

The findings of the quantitative study conducted in order to determine the correlation between science teachers serving at the secondary education level use the EBA and their level of using the educational technologies will be presented in three sections.

\section{Findings about the Opinions of Science Teachers concerning the Level of Use of the $\boldsymbol{E B A}$}

The descriptive statistical values concerning each item belonging to the 3 factors included in the questionnaire in order to determine the opinions of the teachers concerning the level of use of the EBA are given below. The first factor of the questionnaire is about "teachers' views on EBA", the second factor is "teachers' level of use of EBA" and the third factor is "teachers' solution suggestions for improvement in education and training with EBA". Firstly, the mean and standard deviation values of the statements concerning the opinions of the science teachers about the EBA are given in the Table 2.

Table 2. The mean and standard deviation values of the expressions concerning the opinions of science teachers about the EBA

\begin{tabular}{lcc}
\hline Expressions concerning the Opinions about the EBA & $\boldsymbol{X}$ & $\boldsymbol{S} \boldsymbol{D}$ \\
\hline EBA is a new course material of teachers. & 2.40 & 0.60 \\
With EBA, lessons are more fun. & 2.42 & 0.68 \\
Use of the EBA increases the interest in lessons. & 2.52 & 0.71 \\
Thanks to the EBA, I can hold the attention of my students for a long time. & 2.17 & 0.70 \\
& & 0.83 \\
The school management does not provide the required support concerning the & 1.70 & 0.69 \\
use of EBA. & & 0.63 \\
When I use the EBA, participation in the lessons increases compared to the & 2.47 & 0.57 \\
traditional methods. & 2.56 & 0.61 \\
EBA makes it easier to learn. & 2.47 & 0.83 \\
Thanks to the EBA, I have an easy access to information. & 2.22 & 1.76 \\
In the EBA, I can find answers to my needs concerning the content. & 0.56 \\
It takes too much time for me to access to the content I seek in the EBA. & 2.68 \\
It is beneficial that visual and audio materials can be found together in the & & \\
EBA. & & \\
\hline
\end{tabular}

When the mean values of the expressions concerning the opinions of the participating science teachers concerning the EBA were examined in the Table 2, it can be seen that the highest number of replies they gave to the item of "It is beneficial that visual and audio materials can be found together in the EBA" were within the interval of "Necessary". The lowest number of replies given to the item of "The school management does not provide the required support concerning the use of EBA" were within the interval of "Useful but insufficient". Secondly, the mean and standard deviation values concerning the opinions of the science teachers concerning the level of use of the EBA are given in the Table 3.

Table 3. The mean and standard deviation values concerning the level of use of the EBA by teachers

\begin{tabular}{lcc}
\hline Expressions concerning the level of use of the EBA & $\boldsymbol{X}$ & $\boldsymbol{S D}$ \\
\hline I use visual and audio materials in the EBA. & 2.63 & 0.64 \\
I examine the written sources such as magazines and books in the EBA. & 2.35 & 0.76 \\
I use video / animation materials in the EBA. & 2.60 & 0.64 \\
I use simulation applications in the EBA. & 2.51 & 0.72 \\
I use the test questions in the EBA. & 2.50 & 0.69 \\
I follow the news about current events in the EBA. & 2.12 & 0.81 \\
\hline
\end{tabular}




\begin{tabular}{lll}
\hline I share the videos I have recorded on the EBA. & 1.70 & 0.80 \\
I play educative game applications on the EBA. & 2.28 & 0.79 \\
I use experiment applications in the EBA. & 2.52 & 0.69 \\
I can easily use the blog pages about the subjects I am interested in. & 2.08 & 0.78 \\
I want my students to search projects in the EBA. & 2.17 & 0.77 \\
I exchange information on the EBA social network structure. & 1.92 & 0.80 \\
I share the activities I prepare on the EBA. & 1.77 & 0.77 \\
I can download course materials from the EBA and make changes in it. & 2.35 & 0.69 \\
I can develop contents for my lessons in the EBA. & 1.98 & 0.77 \\
I encourage students to use the EBA. & 2.58 & 0.60 \\
\hline
\end{tabular}

As can be seen in the Table 3, it was found out when the mean and standard deviation values concerning the level of use of the EBA by the science teachers were examined that the highest number of replies given to the item of "I use visual and audio materials in the EBA" were within the interval of "Necessary". The lowest number of replies given to the item of "I share the videos I have recorded in the EBA" were within the interval of "Useful but insufficient". Lastly, the mean and standard deviation values concerning the solution offers of the teachers concerning the improvement of the education carried out by means of the EBA are given in the Table 4.

Table 4. The mean and standard deviation values concerning the solution offers about the improvement of the education carried out by means of the EBA

\begin{tabular}{lcc}
\hline Expressions concerning the Solution Offers about the Improvement of the & $\boldsymbol{X}$ & $\boldsymbol{S D}$ \\
Education carried out by means of the EBA & & 0.55 \\
\hline I think EBA can contribute positively to the solution of the problems related to & 2.62 & 0.60 \\
education. & 2.60 & 0.67 \\
I believe EBA will contribute to the improvement and quality of education. & 0.63 \\
I believe that EBA will be a solution for the information pollution on the & 2.43 & 0.59 \\
Internet. & 2.48 & 0.71 \\
I think EBA has contributed to the quality of the education program. & 2.57 & 0.71 \\
I think the EBA will use the technology as a means rather than an end. & 2.28 & 0.65 \\
I think EBA will decrease my workload. & 2.46 & 0.60 \\
I think EBA has a positive effect on the motivation of teachers. & 2.42 & 0.67 \\
I think EBA gathers all teachers at a common ground and gives the education a & & 0.80 \\
direction based on cooperation. & 2.61 & 2.51 \\
I think EBA suitable for students having different learning styles (verbal, \\
numerical, visual, social, individual, and audio). & 2.38 \\
I think EBA should be used in the curriculum. & & \\
The teachers should be given in-service training on how to use the EBA more \\
efficiently in education.
\end{tabular}

When the means of the opinions of the participating teachers concerning the improvement of education by means of the EBA were examined, it was seen that the highest number of replies given to the item of "I think it can contribute positively to the solution of the problems related to education" were within the interval of "Necessary". The lowest number of replies given to the item of "I think the EBA will decrease my workload" were within the interval of "Useful but insufficient". Since the data does not display a normal distribution in the present study, it is necessary to use the Mann-Whitney U test and the Kruskal-Wallis test.

Table 5. The Mann-Whitney U test of the scale for the opinions concerning the level of use of the EBA by gender

\begin{tabular}{lllllll}
\hline & Gender & $\mathbf{N}$ & $\begin{array}{l}\text { Mean } \\
\text { Rank }\end{array}$ & $\begin{array}{l}\text { Total } \\
\text { Rank }\end{array}$ & U & p \\
\cline { 1 - 5 } Mean of the opinions concerning the EBA & Female & 56 & 40.44 & $2,264.50$ & \\
\cline { 2 - 3 } & & &
\end{tabular}




\begin{tabular}{lcccccc}
\hline & Male & 24 & 40.65 & 975.50 & 668.5 & 0.97 \\
Mean of the level of use of the EBA & Female & 56 & 40.61 & $2,274.00$ & & \\
& Male & 24 & 40.25 & 966.00 & 666.0 & 0.95 \\
Mean of the solution offers concerning the & Female & 56 & 40.36 & $2,260.00$ & & \\
improvement of education by means of the & Male & 24 & 40.83 & 980.00 & 664.0 & 0.93 \\
EBA & & & & & & \\
\hline
\end{tabular}

Mann-Whitney U test was conducted to determine whether the mean of science teachers' views on EBA differs significantly according to gender in the study. It can be seen in Table 5, there is no significant gender-based difference among Science Teachers in terms of "the means of their opinions of on the EBA", "the means of their use of the EBA" and "the means of their suggestions concerning the improvement of training-education through the EBA". To sum up, the scale of opinions concerning the use of the EBA do not differ significantly depending on the gender.

Table 6. The Kruskal Wallis test results according to the professional service year variable of the scale of opinions on the level of use of EBA

\begin{tabular}{|c|c|c|c|c|c|}
\hline & $\begin{array}{l}\text { Duration of } \\
\text { Professional } \\
\text { Service }\end{array}$ & $\mathbf{N}$ & Mean Rank & p & $\overline{K^{2}}$ \\
\hline \multirow[t]{4}{*}{ Mean of the opinions concerning the EBA } & $1-5$ years & 15 & 26.60 & & \\
\hline & $6-10$ years & 41 & 42.43 & & \\
\hline & $11-15$ years & 11 & 40.50 & 0.074 & 8.520 \\
\hline & $16-20$ years & 12 & 51.63 & & \\
\hline \multirow[t]{4}{*}{ Mean of the levels of use of the EBA } & $1-5$ years & 15 & 29.20 & & \\
\hline & $6-10$ years & 41 & 38.68 & & \\
\hline & $11-15$ years & 11 & 42.77 & $0.022^{*}$ & 11.444 \\
\hline & $16-20$ years & 12 & 58.88 & & \\
\hline \multirow{4}{*}{$\begin{array}{l}\text { Mean of the solution offers concerning the } \\
\text { improvement of the education and training } \\
\text { by means of the EBA }\end{array}$} & $1-5$ years & 15 & 31.53 & & \\
\hline & $6-10$ years & 41 & 42.22 & & \\
\hline & $11-15$ years & 11 & 39.82 & & \\
\hline & $16-20$ years & 12 & 46.54 & 0.506 & 3.320 \\
\hline
\end{tabular}

Kruskal Wallis test was conducted in the study to determine whether the views of science teachers about the level of use of EBA show a significant difference according to years of professional service. It can be seen when Table 6 was examined that there is no significant difference among Science Teachers in terms of the means of their opinions on the EBA and the means of their opinions on the level of use of the EBA depending on their duration of service. It can be seen that there is a significant difference among Science Teachers only in terms of their level of use of the EBA depending on their duration of service $(p=0.022$; $\mathrm{p}<0.05$ ). Accordingly, the level of use of the EBA is the highest among the Science Teachers with duration of service in the profession between 16 and 20 years. The findings suggest that there is a positive linear correlation between the level of use of the EBA and the duration of service in the profession.

\section{Findings Concerning the Opinions of the Science Teachers about the Level of Use of the Educational Technologies}

In the research, the relevant descriptive statistics values of each item belonging to the 4 factors in the questionnaire are given below in order to determine the opinions of teachers about the level of use of educational technologies. In the questionnaire, the first factor is classified as "Technology literacy", the second one is "Technology integration into the 
course", the third one is "Social ethics and legal provisions" and the fourth one is "Communication". First, the mean and standard deviation values of the statements of science teachers about technology literacy and educational technology usage levels of science teachers are given in Table 7.

Table 7. The mean and standard deviation values of the statements of the teachers concerning the technological literacy

\begin{tabular}{lcc}
\hline Statements concerning the Technological Literacy & $\boldsymbol{X}$ & $\boldsymbol{S D}$ \\
\hline I can set up an operating system again. & 2.36 & 1.55 \\
I store my data on the Internet (google drive, Dropbox, e-mail, etc.) & 3.62 & 1.41 \\
I can make modifications such as resolution and size on a picture. & 3.77 & 1.38 \\
I can format usb flash drives. & 3.92 & 1.32 \\
I can carry out conversions between file formats (mp3-wav, avi-mpeg, bmp-jpg etc.). & 3.76 & 1.30 \\
I can perform video chats over the Internet. & 4.10 & 1.34 \\
I can prepare a presentation by using multimedia materials. & 4.78 & 5.79 \\
I can prepare a video by using multimedia materials (sound, pictures, texts, etc.) & 3.76 & 1.44 \\
I can perform the advanced settings concerning the volume control. & 3.56 & 1.38 \\
I can effectively use an antivirus program. & 3.77 & 1.54 \\
I can build an internet site by using free templates. & 2.77 & 2.67 \\
I can set up the software by downloading it from the Internet or from a CD. & 3.46 & 1.34 \\
I can share files through wireless networks (wireless, Bluetooth, infrared, etc.). & 4.42 & 1.08 \\
I can create passwords against the threats that may come through the wireless network. & 3.61 & 1.37 \\
I can install applications in mobile devices. & 4.38 & 1.11 \\
I can carry out the display unit settings of the computer. & 4.05 & 3.66 \\
I know the difference between the file sizes and the storage units. & 4.02 & 1.21 \\
I know about the frequently used file formats (pdf, doc, exe, ppt, xls). & 4.31 & 1.03 \\
I can easily adapt to the technologies I encounter for the first time. & 3.97 & 1.19 \\
\hline
\end{tabular}

According to results on the means of the expressions concerning the opinions of the participating science teachers about the technological literacy, the highest number of answers given to the item of "I can prepare a presentation by using multimedia elements" were within the interval of "Strongly Agree". It was determined that they gave the lowest answer corresponding to "Strongly Disagree" range to the item "I will reinstall an operating system". Secondly, the mean and standard deviation values of the expressions concerning the opinions of the science teachers about the integration of technology into the lessons are given in the Table 8.

Table 8. Mean and standard deviation values of the statements of the teachers concerning the integration of technology into the lessons

\begin{tabular}{lcc}
\hline Statements concerning the Integration of Technology into the Lessons & $\boldsymbol{X}$ & $\boldsymbol{S D}$ \\
\hline I design materials that support the student-centered activities. & 3.86 & 0.97 \\
I know there is a need to make preparations before using the technology in lessons. & 4.33 & 1.05 \\
I select and use different technologies for obtaining different gains. & 4.00 & 1.06 \\
I come up with alternative solutions for the problems that I may encounter while using the & 3.95 & 1.04 \\
technology in my lessons. & 4.00 & 1.16 \\
I download teaching materials from the Internet and modify them. & 4.01 \\
I can set up package educational software (animation, simulation, package trainer, etc.) to & 1.15 \\
my computer and use them. & 4.18 \\
I make use of technology in order to support the individual learning of the students. & 4.00 \\
While designing materials, I act in accordance with the teaching design principles. & 1.08 \\
I follow the web sites that can contribute to my professional development. & 4.25 & 1.00 \\
\hline
\end{tabular}

As can be seen in the Table 8, it was found out when the mean and standard deviation values 
of the statements concerning the opinions of the science teachers about the integration of the technology into the lessons were examined that the highest number of replies given to the item of "I know there is a need to make preparations before using the technology in lessons" were within the interval of "Strongly Agree". It was also seen that the lowest number of replies given to the item of "I design materials that support the student-centered activities" were within the interval of "Agree". Thirdly, the mean and standard deviation values of the statements concerning the opinions of the science teachers about the social ethics and legal provisions are given in the Table 9.

Table 9. Mean and standard deviation values of the statements of the teachers concerning the social ethics and legal provisions

\begin{tabular}{lcc}
\hline The Statements concerning the Social Ethics and Legal Provisions & $\boldsymbol{X}$ & $\boldsymbol{S D}$ \\
\hline I do not accept the accuracy of every information on the internet, but rather I question it. & 4.38 & 1.04 \\
I know that I must state the source of the information I use. & 4.42 & 0.97 \\
I act in accordance with the legal responsibilities concerning the copyrights. & 4.22 & 1.04 \\
I am careful in sharing personal information and its confidentiality. & 4.53 & 0.91 \\
I am aware of the responsibilities that my shares in social settings lay on me. & 4.47 & 0.95 \\
I know and be cautious about cyber-crimes. & 4.56 & 0.85 \\
\hline
\end{tabular}

As can be seen in the Table 9, it was found out when the means of the expressions concerning the opinions of the science teachers about the social ethics and legal provisions were examined that the highest number of replies given to the item of "I know about and observe cyber-crimes" were within the interval of "Strongly Agree". It was also seen that the participant agreed at a high level with the other five items as well. Lastly, the mean and standard deviation values of the statements concerning the opinions of the science teachers about communication are given in the Table 10 .

Table 10. Mean and standard deviation values of the statements of the teachers concerning the communication

\begin{tabular}{lcc}
\hline Statements concerning Communication & $\boldsymbol{X}$ & $\boldsymbol{S D}$ \\
\hline I can prepare online examinations and apply them to my students. & 2.73 & 1.43 \\
I use online systems to establish mass communication with the parents and students. & 3.03 & 1.55 \\
I guide students in the active use of e-mail groups. & 3.07 & 1.49 \\
I share educational materials with my students over the social networks. & 2.97 & 1.55 \\
\hline
\end{tabular}

When the means of the expressions concerning the opinions of the science teachers about communication are checked in Table 10, they seemed to give the replies falling in the interval of "Undecided" to all items. The Mann-Whitney U test was conducted to determine whether the opinions of the science teachers on the level of use of the educational technology significantly differed depending on their gender.

Table 11. The Mann-Whitney $U$ test of the level of use of the educational technologies by the teachers

\begin{tabular}{|c|c|c|c|c|c|c|}
\hline & Gender & $\mathbf{N}$ & $\begin{array}{l}\text { Mean } \\
\text { Rank }\end{array}$ & $\begin{array}{l}\text { Total } \\
\text { Ranks }\end{array}$ & $\overline{\mathbf{U}}$ & $\mathbf{p}$ \\
\hline Technological Literacy & Female & 56 & 35.20 & $1,971.00$ & & \\
\hline & Male & 24 & 52.88 & $1,269.00$ & 375.00 & 0.002 \\
\hline Integration of & Female & 56 & 37.04 & $2,074.50$ & & \\
\hline into the Lessons & Male & 24 & 48.56 & $1,165.50$ & 478.50 & 0.042 \\
\hline Social Ethics & Female & 56 & 41.37 & $2,316.50$ & & \\
\hline
\end{tabular}




\begin{tabular}{lllllll}
\hline Provisions & Male & 24 & 38.48 & $923, .0$ & 623.50 & 0.598 \\
Communication & Female & 56 & 38.54 & $2,158.00$ & & \\
& Male & 24 & 45.08 & $1,082.00$ & 562.00 & 0.247 \\
& & & & & & \\
\hline
\end{tabular}

As can be seen in Table 11, according to Mann-Whitney $\mathrm{U}$ test results, there is a significant difference among Science Teachers in terms of their opinions about "Technological Literacy" and "Integration of Technology into the Lessons" depending on their gender (both $p<0,05$ ). When the mean rank is taken into consideration, it is understood that the educational technology usage levels of males are higher than females according to their views on "Technology literacy" and "Technology Integration into Lessons". As is shown in Table 11, there is no significant difference among the Science Teachers in terms of their opinions about "Social Ethics and Legal Provisions" and "Communication" depending on their genders. Thus, it can be said that the opinions of the science teachers concerning "Social Ethics and Legal Provisions" and "Communication" are independent of their gender. In the present study, the Kruskal Wallis test was conducted in order to determine whether the opinions of the science teachers concerning the level of use of the educational technologies differed significantly depending on the duration of professional service.

Table 12. Kruskal-Wallis test of the level of use of the educational technologies by the teachers depending on their duration of professional service

\begin{tabular}{|c|c|c|c|c|c|}
\hline & $\begin{array}{l}\text { Duration of Professional } \\
\text { Service }\end{array}$ & $\mathbf{N}$ & $\begin{array}{l}\text { Mean } \\
\text { Rank }\end{array}$ & $\bar{p}$ & $\mathbf{K}^{2}$ \\
\hline \multirow[t]{4}{*}{ Technological Literacy } & $1-5$ years & 15 & 37.03 & & \\
\hline & $6-10$ years & 41 & 47.40 & & \\
\hline & $11-15$ years & 11 & 42.50 & $0.010^{*}$ & 13.186 \\
\hline & $16-20$ years & 12 & 20.79 & & \\
\hline \multirow{4}{*}{$\begin{array}{l}\text { Integration of technology into the } \\
\text { lessons }\end{array}$} & $1-5$ years & 15 & 42.37 & & \\
\hline & $6-10$ years & 41 & 46.17 & & \\
\hline & $11-15$ years & 11 & 44.32 & $0.003^{*}$ & 15.967 \\
\hline & $16-20$ years & 12 & 17.04 & & \\
\hline \multirow[t]{4}{*}{ Social ethics and Legal Provisions } & $1-5$ years & 15 & 40.13 & & \\
\hline & $6-10$ years & 41 & 43.50 & & \\
\hline & $11-15$ years & 11 & 36.77 & 0.426 & 3.856 \\
\hline & $16-20$ years & 12 & 32.13 & & \\
\hline \multirow[t]{4}{*}{ Communication } & $1-5$ years & 15 & 35.80 & & \\
\hline & $6-10$ years & 41 & 46.90 & & \\
\hline & $11-15$ years & 11 & 38.41 & 0.090 & 8.040 \\
\hline & $16-20$ years & 12 & 28.13 & & \\
\hline
\end{tabular}

Based on the results of the Kruskal-Wallis Test conducted in order to determine whether the level of use of the educational technologies by the science teachers significantly differ depending on the variable of the duration of professional service, it was found out that both the technology literacy and the integration of the technology into the lessons differed significantly depending on the duration of professional service. As can be seen in Table 12, there is a significant difference among Science Teachers in terms of their "technological literacy" and "integration of the technology into the lessons" depending on their duration of service. When the mean rank is taken into consideration, the "technological literacy" of and "integration of the technology into the lessons" by the science teachers with a duration of professional service between 6 and 10 years is at the highest level compared to the other 
categories of the duration of service. As can be seen in Table 12, the opinions of the Science Teachers on "Social Ethics and Legal Provisions" and "Communication" do not differ significantly depending on the duration of service. The opinions of the teachers on Social Ethics and Legal Provision is independent of their duration of service. When the mean rank is taken into consideration, opinions of the Science Teachers on "Social Ethics and Legal Provisions" and "Communication" are independent of the variable of the duration of service.

\section{Findings Regarding the Correlation between the Opinions of the Science Teachers on the Level of Use of the Education Information Network and the Level of Use of the Educational Technologies}

Finally, the correlation between the teachers' opinions on the level of EBA use and their views on the level of educational technologies use was examined in the study. In cases where the data distribution was not normal (in non-parametric tests), Spearman Brown rank correlation coefficient was used to explain the relationship between the two variables. The results of the correlation between the questionnaire for the opinions of the science teachers concerning the level of use of the EBA and their opinions concerning the use of educational technologies are given in the Table 13.

Table 13. Correlation test concerning the level of use of the EBA and the educational technologies by the teachers

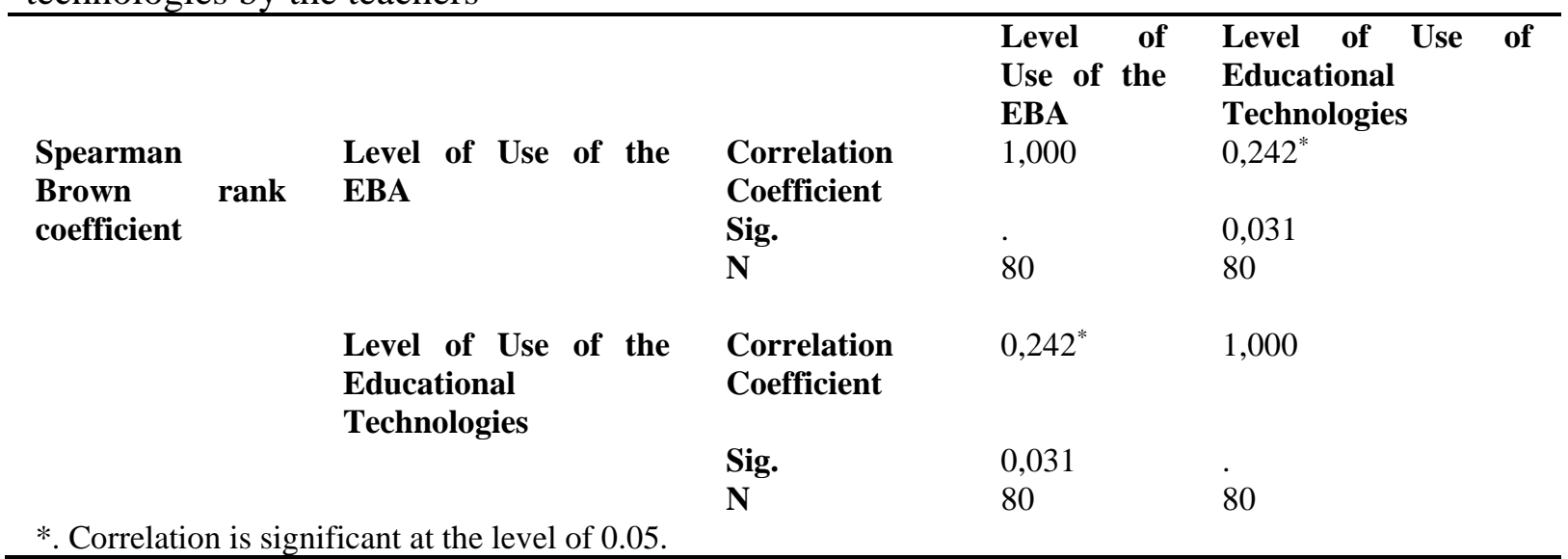

As can be seen in the Table 13, there is a slight, positive, and significant correlation between the level of use of the EBA and the level of use of the educational technologies $\left(r=0.242^{*}\right.$, $\mathrm{p}<0.05)$. Büyüköztürk (2012) states that if a ' $r$ ' value obtained by means of the correlation analysis is between 0.00 and 0.30 , this is defined as a slight correlation.

\section{Discussion and Conclusion}

It has been determined that the means of the science teachers' opinions agreeing on the statements on educational information network is positively high. The expressions concerning the Education Information Network that were considered to be positive were, in general, that it was beneficial that visual and audio materials can be found together in the EBA, that it made it easier to learn, that it increased the interest in the lessons, and that it increased the participation of the students in the lessons. According to Güvendi's (2014) study, it was concluded that teachers use EBA to get information rather than sharing. In addition, Dursun et al. (2013) stated in their study that innovations such as the Fatih Project facilitate teachers in the teaching-learning process. Besides, they emphasized that accessing the visual and 
auditory information on the internet during the lesson and enriching the topics covered with the support of visual content are considered as a great convenience during the teaching process. It was also stated in their study based on the observation both in science and mathematics courses and social/verbal courses that visual content was frequently used. The results of that study are in congruence with the findings of the study conducted by Kirali (2013), which suggested that the courses had become more pleasurable and interesting due to the software in tablets and PCs, and students could focus and hold their attention easily while using tablets and PCs.

When the findings regarding the level of use of the EBA by the science teachers are examined, it is seen that that their rate of agreeing the statements is half and half, as they use it in the teaching-learning process. In particular, the teachers stated that the most preferred contents were the visual and audio materials, video/animation materials, experiment applications, simulation applications and test questions. They also stated that they encouraged the use of the EBA, and they both benefited from and used it. In this context, it was seen that the science teachers used the EBA mostly to support the lessons visually and in the experiments or activities that were difficult to perform. According to Tutar's study (2015) the primary objectives of the use of the EBA to be obtaining documents and using the e-content and e-book part. Güvendi (2014) found out based on the findings of the study he conducted that teachers mostly read the news on the EBA website, made use of the educational content in the EBA, and benefited from the electronic versions of the textbooks in the EBA. It can be said that those findings are in general coincide with the results of the present study. In addition, it was seen based on the findings concerning the level of use of the EBA by the science teachers that their rate of agreeing the expressions such as developing contents for the lessons, sharing information and sharing the activities they prepared on the EBA was stated to be "Useful but insufficient". This result is in congruence with the findings obtained in the study of Polat (2014) that the candidate teachers had worries about developing content.

When the findings concerning the solution offers of the science teachers about the improvement of the education and training by means of the EBA were examined, their rate of agreeing on the statements were found to be high in the positive direction. In particular, it is seen that teachers agree with the high participation rate, in terms of EBA's positive contributions to teaching problems and the education system. They also stated that the use of the EBA would be helpful in terms of the individual differences of students in the process of learning. In addition, the teachers agreed with a high level of participation, that the EBA would provide motivation in professional terms and contribute to the education by gathering colleagues at a common ground. The teachers stated to be undecided only about the opinion that the EBA would decrease their workload.

It was determined in the present study that there were no statistically significant differences among the means of the opinions of the science teachers about the EBA, the mean of their level of use of the EBA and the mean of their solution offers concerning the improvement of the education and training by means of the EBA depending on the gender.

The mean of the opinions off the science teachers about the EBA do not differ depending on their duration of professional service. Besides, the means of the solution offers concerning the improvement of the education and training by means of the EBA do not differ significantly depending on the duration of professional service, either. It was determined that only the means of the opinions concerning the level of use of the EBA differed significantly depending on the duration of professional service. This result suggests that the teachers with a less 
duration of service in the profession (between 6 and 10 years) could use the technology in an easier way in teaching Science. It was determined that the competence of the teachers with more duration of professional service had a lower mean value. Secondly, the results of the findings obtained in the present study, which was conducted in order to determine the opinions of the science teachers concerning the level of use of the educational technologies are given below.

The means of the replies in which the science teachers agreed the statements concerning the technological literacy were found to be high in positive direction. The positive statements concerning the technological literacy were, in general, the preparation of presentations, sharing files and installation of applications in mobile devices. In the literature, the study by Varış (2008) was conducted in order to determine the level of the information technologies literacy of the teachers serving at primary education schools and their status in terms of using such technologies. In that study, the professional seniority of the teachers was found out to be an effective variable concerning the information technologies literacy. It was determined that the teachers with less seniority in the profession made more use of the information technologies in the preparations before the lessons, in their own professional development and in assessment and evaluation. In the study conducted by Akpinar (2003), the extent to which teachers made use of the technological opportunities and the effect of the higher education they have received on this were investigated. Significant differences were found in the use of internet resources in the course according to the higher education institutions they studied. It can be said that the results of the present study are in congruence with the findings obtained in previous studies.

All of the means of the replies in which the science teacher agreed the statements concerning the integration of the technology into the lessons were found to be high in the positive direction. The positive statements concerning the integration of the technology into the lessons are namely, making preliminary preparations, supporting the individual learning of the students and them, following different Internet sites for their professional development. In the study conducted by Rüzgâr (2005), the branches of teachers were determined to be an important variable in terms of making use of the educational technologies. The study found out that teachers used the products of educational technology depending on their branches and the content of the courses. Demiraslan and Usluel (2005) investigated, in their study, the status of teachers in terms of their integration the information technologies into the lessons in the process of learning-teaching. Based on the findings of the study, it was found out that the majority of the teachers could use computers but did not carry out any activity concerning the integration of the information and communication technologies into the process of learningteaching.

It was determined that all of the means of the replies in which the science teacher agreed the statements concerning the social ethics and legal provisions were high in the positive direction. It was found out with the highest mean that they are aware of cybercrimes, and they were cautious in sharing personal information and its confidentiality.

Lastly, it was found out that the teachers were undecided about all of the statements concerning the communication. It was determined that the science teachers were undecided concerning getting into contact with the parents of the students and sharing educational materials out of the school setting by means of the social networks. Consequently, it was found out that the opinions teachers concerning the level of use of the technology was positive. 
In the analysis of the levels of use of the educational technologies by the science teachers, the means of the technological literacy and integration of the technology into the lessons were found to be higher in male participants compared to the female participants. Likewise, it was also found out that the means of the opinions of the science teachers concerning the social ethics and legal provisions and concerning the communication did not differ significantly depending on their gender.

As for the level of use of the educational technologies, significant differences were found both in the technological literacy and in the integration of the technology into the lessons depending on the duration of professional service. Based on the mean ranks, it was found out that the teachers whose duration of professional service was between 6 and 10 years, who were relatively new in the profession, were more successful in technological literacy and in integrating the technology into the lessons since their level of using the technology is better. In addition, the opinions concerning the social ethics and legal provisions and concerning the level of use of the communication were found not to differ significantly depending on the duration of professional service.

When the correlation between the questionnaire for the opinions of the teachers concerning the level of use of the EBA and the questionnaire for the opinions concerning the level of use of the educational technologies were examined, it was found out that there was a slight, positive, and significant correlation between the level of use of the EBA and the level of use of the educational technologies. $\left(r=0.242^{*} \mathrm{p}<0.05\right)$. Based on this result, since the ' $r$ ' value is between 0.00 and 0.30 , the correlation is considered to be slight.

\section{Suggestion}

Based on the results obtained in the present study, the following recommendation can be made:

It should be ensured that the infrastructural deficiencies of the EBA application had to be solved thus every student and teacher can use the application without experiencing any systemic problems.

The content of the applications should be improved, that the teachers and the students will be able to easily access videos, pictures, experiments, and exercises.

In order to ensure that teachers and students can easily access the EBA application, it is necessary to provide them with PC and tablet. Likewise with a view to increasing the use of the EBA application by teachers, it should be ensured that the content that is suitable for using during the lessons are uploaded into the system. Especially in the lessons where abstract subjects are taught, the experiments and simulations in the content should be increased since they will render the lessons more understandable.

In schools, encouraging of the students to increase their use of the EBA and the seminars given to them by the Information Technologies Teachers can be effective.

Content that will allow the students to review the subjects and to enhance their understanding of the subjects by means of solving a lot of questions can be uploaded into the EBA and they can be encouraged to use such contents. The need for additional source materials should be met by teachers over the EBA application. 


\section{References}

Alabay, A., \& Taşdelen, V. (2017). Secondary education teachers and students views on the use of EBA (informatics network in education) a Study. Istanbul Aydin University Journal of Education Faculty, Special Issue, 27-29.

Akpinar, Y. (2003). The effect of higher education on teachers' use of new information technologies: The case of Istanbul schools. The Turkish Online Journal of Educational Technology, 2(2), 1303-6521.

Akpınar, E., Aktamış, H., \& Ergin, O. (2005). Students' opinions on the use of educationaltechnology in science lesson. The Turkish Online Journal of Educational Technology, 4(1), 93-100.

Aktay, S., \& Keskin, T. (2016). Education Informatics Network (EBA) review. Journal of Educational Theory and Practice Research, 2(3), 27-44.

Arkan, A., \& Kaya, E. (2018). Education Information Network (EBA) and 2023 Education Vision. Seta Perspektif, Issue 221.

Bayraktar, R. (2015). Determining Teachers' Level of Use of Educational Technologies: Scale Development Study. Master Thesis, Karadeniz Technical University Institute of Educational Sciences, Trabzon.

Bertiz, Y. (2017). Evaluation of the usability of online social education platforms: Education Informatics Network (EBA) system example. Science, Education, Art and Technology Journal (BEST Magazine), 1 (2), 63-76.

Bolat, Y. (2016). Inverted classrooms and education information network (EBA). Journal of Human Sciences, 13(2), 3373-3388.

Büyüköztürk, Ş., Çakmak,E., Akgün, Ö.,E., Karadeniz, Ş., \& Demirel, F., (2012). Scientific Research Methods. Ankara, 13th Edition, Pegem Academy.

Çakmak, Z., \& Taşkıran C. (2017). From the perspective of social studies teachers educational informatics network (EBA) Platform. International Journal of Turkish Educational Sciences, 9, 284-295.

Demir, D., Özdinç F., \& Ünal E. (2018). Investigation of participation in education information network (EBA) portal. Erzincan University Journal of Education Faculty, 2, 407-422.

Demiraslan, Y., \& Usluel, Y. K. (2005). The status of teachers in the integration of information and communication technologies into learning and teaching process. The Turkish Online Journal of Educational Technology, 4(3), 109-113.

Demirhan, S. (2012). Science and technology teachers' self-efficacy perceptions of information and communication technologies and usage of information and communication technologies. Master Thesis, Pamukkale University Institute of Science, Denizli.

Durmuşçelebi, M., \& Temircan, S. (2017). Evaluation of educational materials in education informatics network according to student opinions. International Journal of Society Researches, 7, 13, 632-652.

Dursun, Ö.Ö., Kuzu, A., Kurt, A.A., Güllüpınar, F., \& Gültekin, M. (2013). School administrators' views on the pilot implementation process of fatih project. Trakya University Journal of Education, Vol 3, Issue 1, 100-113.

EBA (2019). Introduction about EBA. It is taken from http://www.eba.gov.tr

Fidan, N. K., Erbasan, Ö., \& Kolsuz, S. (2016). Classroom teachers' opinions about benefiting from Education Informatics Network. International Journal of Social Research, 9 (45), 626-637.

Gülcü, A., Solak, M., Aydın,S., \& Koçak, Ö. (2013). Opinions of subject teachers working in primary education regarding the use of technology in education. International 
Periodical For The Languages, Literature and History of Turkish or Turkic, Volume 8/6 Spring 2013, p. 195-213.

Güvendi, G.M. (2014). Determining the frequency of teachers' use of online education and sharing sites offered by the Ministry of National Education to teachers: The example of educational information network (EBA). (Unpublished Master's Thesis), Sakarya University Institute of Educational Sciences, Sakarya.

Kalemkuş, F. (2016). Secondary education teachers 'and students' views on education informatics network (EBA). Master's Thesis, Afyon Kocatepe University Institute of Science, Afyon.

Kapıdere, M. \& Çetinkaya, H., N. (2017). Evaluation of education informatics network

(EBA) mobile application. International Journal Of Active Learning, 2 (2), 1-14.

Karasar, N. (2005). Scientific research method. Ankara: Nobel Broadcast Distribution.

Kirali, F.N. (2013). Student opinions on Tablet-Pc applications distributed within the scope of fatih project. Master's Thesis, Bahçeşehir University Institute of Science, Istanbul.

Kuyubaşığlu, M. \& Kılıç, F. (2019). Investigation of the usage levels of the informatics network (EBA) in education according to the views of secondary school teachers. Journal of Advanced Education Studies, 1 (1): 32-52.

Polat, E. (2014). Evaluation of teacher candidates' E-content development skills within the framework of fatih project. Master Thesis, Firat University Institute of Educational Sciences, Elazı̆g.

Rüzgar, B. (2005). Sharing of knowledge in education by using educational technologies. Turkish Online Journal Of Educational Technology, 4 (3).

Saklan, H. \& Ünal, C. (2018). Technology-friendly science teachers' views on education information network (EBA). Necatibey Faculty of Education Electronic Science and Mathematics Education Journal, 12, 1, 493-526.

Tekin, H. (1993). Measurement and evaluation in education. Ankara: Yarg1 Publishing House.

Timur, B., Yılmaz, Ş., \& İşseven, A. (2017). Secondary School Students' Views on Using the Educational Informatics Network (EBA) System. Asian Journal of Instruction, 5 (1), 44-54.

Tutar, M. (2015). Evaluation of teachers' views on the education information network (EBA) site. Unpublished Master's Thesis, Karadeniz Technical University Institute of Educational Sciences, Trabzon.

Türk, M., G., (2012). Analysis of teachers' views regarding the use of instructional technologies in their lessons. Master's Thesis, Gazi University Institute of Educational Sciences, Ankara.

Türker, A., \& Güven, C. (2016). Levels of high school teachers' benefiting from education informatics network (EBA) project and their opinions about the project. Journal of Education and Instructional Research, 5 (1), 244-254.

Tüysuz, C. \& Çümen, V. (2016). Secondary School Students' Views on the EBA Course Website. Uşak University Journal of Social Sciences, 9 (3), 278-296.

Ünal,B., B. \& Hastürk, H., G. (2018). The effect of using educational informatics network (EBA) in science course on the circulatory system achievement test results of secondary school students. International Journal of Humanities and Education, 4, 7, 327-342.

Varış, Z. (2008). Determination of information technology literacy levels of teachers in primary schools and their usage. Master Thesis, Gazi University Institute of Educational Sciences, Ankara.

Varışoğlu, B. (2019). Investigation of teachers' educational informatics network (EBA) attitudes. Turkish Studies - Social Sciences, 14, 6, 3511-3521. 
Yıldırım, A. \& Şimşek, H., (2016). Qualitative Research Methods in Social Sciences. Ankara, 10.Bask1, Seçkin Publishing.

Yirci, R. \& Bulduk, E. (2018). Examination of administrator, teacher and student opinions on education informatics network (EBA). 5th International Educational Sciences Symposium, 187-204. 